\title{
Themes, approaches, and methods in the geographical analysis of Czech and Slovak parliamentary elections: a systematic review
}

\section{Dominik Kevický*}

\author{
Masaryk University, Faculty of Science, Department of Geography, Czechia
}

* Corresponding author: kevicky.dominik@mail.muni.cz

\begin{abstract}
This article reviews the field of electoral geography in Czechia and Slovakia. It systematically analyses selected publications to identify the most and least frequently researched topics, theories, and methods. Most of the analyzed studies strived to determine the factors underlying the uneven geographical distribution of election results. Issues of turnout and geographical representation were the least common. The cleavage theory was the most frequently applied theoretical approach, although most studies did not apply any theory. Only one study used the qualitative methodology, whereas the rest relied on quantitative methods. Most often, analyses were performed at the scale of districts and municipalities. The article identifies possible directions for future research in the electoral geography of Czechia and Slovakia.
\end{abstract}

\section{KEYWORDS}

Electoral geography; parliamentary elections; Czechia; Slovakia; systematic review

Received: 3 July 2021

Accepted: 11 November 2021

Published online: 26 November 2021

Kevický, D. (2021): Themes, approaches, and methods in the geographical analysis of Czech and Slovak parliamentary elections: a systematic review. AUC Geographica 56(2), 248-261

https://doi.org/10.14712/23361980.2021.16

(C) 2021 The Author. This is an open-access article distributed under the terms of the Creative Commons Attribution License (http://creativecommons.org/licenses/by/4.0). 


\section{Introduction}

By 2020, 30 years had passed since the first free parliamentary elections in post-socialist Czechoslovakia following the end of the undemocratic regime. A year after that event, the first publication was published on the geographical aspects of those election results (Blažek and Kostelecký 1991). This work was soon followed by other geographical papers. Since the initial description of the geographical distribution of political party support, electoral geography has gradually begun to address other issues related to elections and geography. How is turnout changing in different regions? Is there a difference in the voting behavior of rural and urban areas? What factors influence the distribution of electoral support? The publications were also expanded by various methods through which the authors tried to obtain answers to these questions. After 30 years of developing electoral geography in Czechia and Slovakia, it is therefore time to ask what is known about the geographical distribution of electoral results in these countries, and what, on the contrary, remains hidden.

Several studies have dealt with the state of electoral geography in these two countries (Madleňák 2010; Plešivčák 2014b; Plešivčák et al. 2016). The disadvantage of these studies is however their focus on the development of electoral geography in terms of global trends, where the specific environment of Czechia and Slovakia is considered to a lesser extent only (Madleňák 2010; Plešivčák et al. 2016), or research is concerned with only one selected aspect of electoral geography in the study area (Plešivčák 2014b).

Therefore, the aim of this paper is to systematically search and analyze publications that deal with the issue of electoral geography in both countries and to determine which areas of research are well studied and, conversely, which topics of electoral geography deserve more attention in the future. Specifically, the work will try to answer several questions:

- What topics are covered in the electoral geography publications?

- Upon which theories are the authors' analyses based?

- What methods were used to do this?

- What geographical scale level was used in the research?

The second section will deal with the analysis of the state of knowledge in electoral geography as well as the use of a systematic scientific literature review. The section that follows will then describe the procedure of selecting relevant publications and the method of data extraction and synthesis. The results of the analysis will then be presented in the fourth section. The final part will discuss the results and summarize new findings.

\section{Systematic review as a method of studying the state of electoral geography}

Most studies concerning electoral geography are based on previous findings. However, some studies focus purely on determining the state of knowledge. They usually work on a certain area and period in which they show the progress of electoral geography. These studies use various maps and statistical outputs (e.g., Clem 2006; Zarycki 2015; van Hamme et al. 2018). Other works compare the development of electoral geography in different areas and point out similarities and differences (e.g., Johnston 2005). One way to capture the state of knowledge is to analyze the available literature; this reveals not only wellknown topics but also topics that deserve more attention (e.g., Weaver 2014). Two possible methods of literature analysis are the bibliometric analysis (Leib and Quinton 2011; Jokić et al. 2019) and the systematic review.

The systematic review is the application of scientific strategies that limit bias through systematic assembly, critical appraisal, and synthesis of all relevant studies on a specific topic (Cook et al. 1995). While it is commonly used in medical studies (e.g., Cook et al. 1995; Wright et al. 2007), systematic reviews have emerged in several other scientific fields (e.g., Lösel et al. 2018; Novotný et al. 2018).

Only a handful of systematic reviews have been created on the topic of electoral geography, and the topic has usually been connected with other topics such as political brands (Nielsen 2017), disability (Virendrakumar et al. 2018), or education (Manning and Edwards 2014). A systematic review therefore is necessary in order to discover and make systematic the knowledge about the geography of electoral results in Czechia and Slovakia since 1989.

Before proceeding with the review, let us first explore the state of knowledge in world electoral geography. For Reynolds (1990), research in electoral geography has tended to focus on one of three issues: The first is the geography of voting, where the objective is to explain the spatial pattern of voting in terms of some other mappable characteristics. Second is the geographical influences on voting, where the object is to explain voting based on spatial contexts. Third is the geography of representation, which explores the means through which votes are converted into seats (Reynolds 1990).

Madleňák (2010) identified six current research trends in electoral geography: (1) the contextual approach, where the study of the neighborhood effect plays a significant role; (2) the identification of factors which determine elections; (3) the difference between urban and rural voters; (4) the spatial context of election campaigns; (5) the spatial aspects of political participation and representation; and (6) the spatial organization of elections. 
Leib and Quinton (2011) analyzed 224 articles from 1990 to 2007 and grouped electoral geography studies into four broad categories. The largest category is called "vote studies," which examine the spatial distribution of compositional factors or place-based contextual factors. This category covers a large variety of topics like the difference between city and suburban voters, turnout distribution, and others. The second category is "electoral system research," which approached the issue of voting systems from several directions. The third concerns discussions and examinations of the (re)districting process, while the last grouping attempts to find methods of bring electoral studies into the classroom. The authors also claimed that almost all electoral geography studies are situated within the spatial-analytic tradition; however, in recent years, studies from post-structuralist viewpoints have grown in popularity.

\section{Methods}

In the selection of suitable publications, only publications which dealt with parliamentary elections and the analysis of the intrastate geographical distribution of these election results were included. No restrictions were placed on the research design or methods used, and both quantitative and qualitative works were selected. However, publications lacking a geographical aspect were excluded. The focus on parliamentary elections was chosen for several reasons. In both countries surveyed, parliamentary elections are the most important of the elections thanks to the large amount of interest they attract (Kostelecký et al. 2015) - hence why most professional publications deal with them. Other options were not included due to the scope of this work.

The publications were first found in the Web of Science (WoS) and Scopus databases in November and December 2020 via searches for the terms "parliamentary election," "Slovakia," "Slovak Republic," "Czechia," "Czech Republic," and "Czechoslovakia" within the article, book, or book chapter categories. Other relevant articles, books, or book chapters were identified by screening references in relevant studies found in the database searches. Studies in English, Czech, and Slovak published between 1990 and 2020 were chosen.

During the database search, duplicate records and studies unrelated to the topic were discarded based on the title or abstract. Reference screening was then performed on the remaining studies so as to identify the largest possible list of relevant publications not included in the databases. Subsequently, articles were read in full; publications without a sufficient geographical aspect - they focused on elections only at the state level - or works with content similar to or duplicated in other studies (and thus not providing new, added information) were excluded.
During the data extraction phase, information on the topic of study, theoretical concepts, analytical methods, and geographical scale of analysis was gathered from the articles.

After the extraction of this information from the studies, the articles were grouped based on information similarity. Individual groups are discussed in more detail in the following section.

\section{Results}

\subsection{Final sample of studies}

Initial searches on Web of Science and Scopus yielded 332 unique studies, of which 305 were excluded by eliminating duplicates and screening titles and abstracts. An additional 78 potentially relevant studies were identified using the snowballing technique. This strategy yielded 105 studies, which were analyzed in full. Three of these were excluded due to insufficient geographical aspects. In the next step, three additional studies were excluded as their content was duplicated in other studies. The final sample for data extraction therefore consisted of 99 unique studies. Only nine of them were published in foreign publications, with the remainder being published in Czech (37) or Slovak (53) journals or books. Table 1 shows the characteristics of these studies in more detail.

Tab. 1 Categorization of studies by publication year and type.

\begin{tabular}{|l|c|c|c|c|c|c|}
\hline & $\begin{array}{c}\text { WoS } \\
\text { journal }\end{array}$ & $\begin{array}{c}\text { Scopus } \\
\text { journal }\end{array}$ & $\begin{array}{c}\text { Other } \\
\text { journal }\end{array}$ & Book & $\begin{array}{c}\text { Book } \\
\text { chapter }\end{array}$ & Total \\
\hline $1991-2000$ & 1 & 5 & 6 & 1 & 1 & 14 \\
\hline $2001-2010$ & 2 & 0 & 12 & 2 & 2 & 18 \\
\hline $2011-2020$ & 17 & 12 & 18 & 9 & 11 & 67 \\
\hline Total & 20 & 17 & 36 & 12 & 14 & 99 \\
\hline
\end{tabular}

These studies were divided into 9 categories based on the topic of study, 7 categories based on theoretical concepts, 17 categories based on analytical methods, and 7 categories according to the geographical scale of analysis. An overview of the extracted information from each study is shown in appendix 1 .

\subsection{Topics of study}

The studies have been divided into nine thematic groups and are presented below followed by a description and starting with the most numerous, which includes 19 studies dealing with factors that influence geographical differences in electoral results. These studies are distinguished by theories and methods used to identify key factors influencing election results. Some studies do not work with any theories (Krivý et al. 1996; Kostelecký 2001; 2009; Spurná 2008; Plešivčák 2011b; 
Gurňák and Mikuš 2012; Nestorová-Dická and Molnár 2013; Bahna and Zagrapan 2017), whereas the most common theory used is cleavage theory (Kostelecký 1994; Plešivčák 2014b; Baboš and Malová 2015; Voda 2015; Voda and Pink 2015) and the effect of contextual factors on election results (Kouba 2007; Bernard et al. 2014; Maškarinec 2014; Mikešová 2019). One study works with grievance theory (Maškarinec and Bláha 2014), and another uses the concept of phantom borders (Šimon 2015).

A frequent geographical study of parliamentary elections in Czechia and Slovakia is a review of specific election results. Authors of these studies often publish follow-up studies (e.g., Krivý 1999; 2003; 2006; 2011; 2012; Krivý and Majo 2018). This type of study was popular among geographers, especially in the early 1990s due to the unavailability of data concerning several elections (Blažek and Kostelecký 1991; Mariot 1991; 1994; 1996). Later, this type of study was used by early sociologists and political scientists (Navrátil 2010; Pink 2011). They are also frequent in books focusing on the political and sociological aspects of elections. In these books, the geographical aspects of the elections form one of several chapters (Krivý 2012; Pink and Voda 2014; Rybář et al. 2017; Krivý and Majo 2018; Voda 2019).

Six studies can be described as analyzing multiple elections. These studies examine changes in the geographical distribution of voting support over time. This type of research is more often published in a separate book (Madleňák 2012; Pink et al. 2012) or a chapter within a book (Jehlička et al. 1993; Gyárfášová and Krivý 2012; Mikuš 2014). Only one study in this category was published in a journal (Madleňák 2006), and the specificity of this publication is its focus on one specific area (Orava region).

Ten studies focus on a particular political party or political family. The main topic of these studies is detailed analysis of the geographical distribution of support for a particular party/family. Authors usually examine traditionally established political parties, such as the communist parties (Kyloušek and Pink 2007), social democratic parties (Kyloušek and Pink 2009), Hungarian parties (Mariot 2003a; Szabó and Tátrai 2016) or the Movement for a Democratic Slovakia (Mariot 2003b). However, there are also studies that focus on new political actors, such as Slovakia's Party of Civic Understanding and Alliance of the New Citizen (Mariot 2004) or the Czech Pirate Party (Maškarinec 2020b). In the last decade, they have come to the forefront of work addressing the issue of populist or radical right-wing parties (Mikuš and Gurňák 2012; 2016; 2019).

Another group of studies focuses on showing the distribution of electoral support for political parties in elections. Until 2015, studies that used a simple map display (Plešivčák 2011a) or Jehlička and Sýkora's (1991) method of identifying electoral support areas dominated (Baráth et al. 1995; Szöllös 2000;
2006; Kostelecký et al. 2015). Since 2015, thanks to Maškarinec (2015; 2017a; 2017b; 2019; 2020a; $2020 b)$, the spatial autocorrelation method has come to the fore, specifically, the analysis of the local indicator of spatial autocorrelation (LISA).

A popular topic of electoral geography is the comparison of voting behavior in urban and rural regions or in border and peripheral areas. Kostelecký and Krivý (2015) examined urban-rural differences in election results in Czechia and Slovakia, while Plešivčák, with a focus on Slovakia, examined the differences between urban municipalities and the countryside (2012a, 2012b, 2012c 2013b, 2014a). Mariot (1999) addressed the issue of voting behavior in cities, Mikuš and Malíková (2015) analyzed voting behavior in marginal rural areas in eastern Slovakia, and Daněk (2000) addressed the issue of peripheral border areas.

In recent years, electoral geographers have also focused on the spatial aspects of voting behavior within the largest cities. For example, Plešivčák (2013a) and Bahna and Majo (2012) analyzed the geography of election results in Bratislava, Kerekeš (2018) analyzed election results in Košice, and Bahna, Kerekeš, and Majo (2018) compared the voting behavior of Bratislava and Košice. Kerekeš (2020) further analyzed election results within Prague's districts. Attention has also been paid to the issue of suburban residential voting behavior. Kostelecký (2005) examined spatial patterns of voting behavior in the metropolitan areas of Prague, Brno, Ostrava, and Pilsen, while Šuška et al. (2018) analyzed the suburban area of Bratislava.

Eleven studies also deal with the issue of electoral geography in the pre-1989 period. They usually work with election results from interwar Czechoslovakia or with the 1946 elections. An exception is a paper by Fnnukal (2008), who examined the 1907 elections to the Austro-Hungarian Imperial Council. The first studies to employ election results from the First Czechoslovak Republic used them in comparison with the results of several political parties (Maškarinec 2011; Kostelecký et al. 2014) or single parties, such as the Communist Party of Bohemia and Moravia (Daněk 1993; Balík 2006) or the Christian and Democratic Union - Czechoslovak People's Party (Voda 2011) in elections after 1989. Later, studies began to solely focus on the geographical aspects of elections from the interwar Czechoslovakia period (Král 2016; Przybyla 2019), with several works analyzing the 1929 election results for their relative proximity in time to the 1930 population census (Šerý and Urbančíkova 2011; Bahna a Krivý 2016; Madleňák and Balažovič 2018).

Only five geographical studies dealt exclusively with the issue of turnout, and all of them have come out in the last 10 years (Mikuš and Gurňák 2014; Nový 2014; Kevický 2020a; 2020b; Kevický and Daněk 2020). These studies seek to map the uneven distribution of turnout, some of which also try to identify several factors influencing voter turnout "maps" in 
Czechia and Slovakia (Kevický 2020b; Kevický and Daněk 2020).

Among the less common topics is the issue of territorial representation. Four of the five studies dealing with this topic concern Slovakia (Brunn and Vlčková 1994; Charvát 2016; Madleňák 2017; 2019), with the remaining study dealing with the Czech territory (Mikešová and Kostelecký 2016). These studies mostly point out that central areas of both Czechia and Slovakia are significantly overrepresented among the deputies, whereas some peripheral areas have no representatives in parliament.

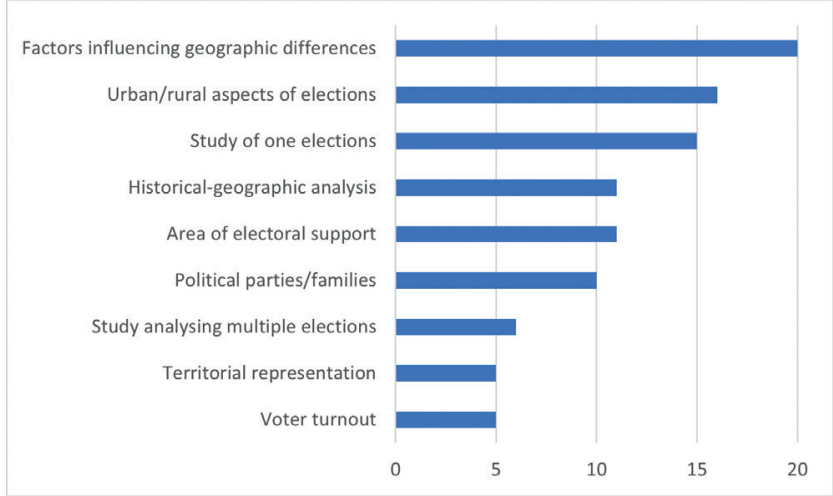

Fig. 1 Division of studies by topic (\%).

\subsection{Theoretical background of study}

As many as 69 studies use no explicit theory and are descriptive only. Among the studies based on theory, cleavage theory is most often applied. Fourteen studies work with this theory, mostly focusing on determining the factors influencing geographical differences in election results (Kostelecký 1994; Plešivčák 2014b; Voda 2015; Voda and Pink 2015; Lysek et al. 2020), on the differences between urban and rural voting (Plešivčák 2013a; 2014a; Kerekeš 2018), and on the examination electoral support for specific political parties/families (Szabó and Tátrai 2016; Mikuš and Gurňák 2019). Cleavage theory was also used by two studies analyzing multiple elections (Madleňák 2012; Pink et al. 2012), and one study focused on a historical-geographic analysis (Madleňák and Balažovič 2018).

Another large group of studies discussed the issue of contextual effects. This theoretical concept is used in studies that focus on determining geographical factors influencing electoral support, such as the effect of friends and neighbors, issue voting, or the neighborhood effect (Kouba 2007; Bernard et al. 2014; Maškarinec 2014; 2015; 2017a; 2017b; 2019; 2020a; 2020b; Mikešová 2019).

Of the studies focused on the issue of turnout, only three make use of theory, for instance, societal modernization theory, mobilization theory, or habitual voting theory (Kevický 2020a; 2020b; Kevický and
Daněk 2020). The remaining studies work with grievance theory (Maškarinec and Bláha 2014), the conceptual sociological structure of city (Kerekeš 2020), and the theory of phantom borders (Šimon 2015).

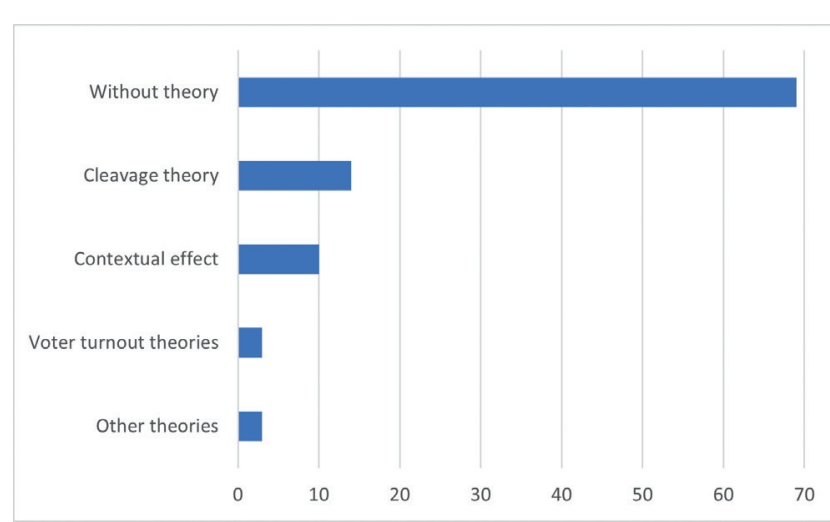

Fig. 2 Division of studies by theoretical background (\%).

\subsection{Methods}

The methods in the analyzed studies can be divided into two groups. The first uses methods that display election results through maps. This method was employed in 61 studies, out of which 23 used straightforward map visualizations displaying election results using a simple cartogram (e.g., above-average/ below-average election support). The delimitation of electoral support areas, proposed by Jehlička and Sýkora (1991), is also used often - 28 studies. This method displays election results and allows for the analysis of their spatial stability. LISA analysis is the least common method of displaying election results and was mainly used by Maškarinec (2014; 2015; 2017a; 2017b; 2019; 2020a, 2020b) but also Kouba (2007) and Kevický (2020b).

The second group employed methods of analyzing election results. Eighteen studies use simple descriptive analysis, in which, for example, regions with the greatest support for political parties are identified or the results of elections are described. This type of method is used mainly by studies focused on one election (e.g., Krivý 1999; 2012) and those focused on the characterization of differences in electoral support between urban and rural areas (e.g., Plešivčák 2012a; 2012b).

Seventeen studies use correlation analysis to identify factors influencing electoral support, and 22 use regression analysis to determine factors influencing the geographical distribution of voting support. Most authors used linear regression analysis. Spurná (2008), Maškarinec (2014; 2020b), and Lysek et al. (2020) work with geographically weighted regression or spatial regression, and Bernard et al. (2014) uses ecological regression.

Studies of territorial representation usually use different methods for the study of proportionality. 
These include the calculation of the least squares index (Charvát 2016) or the index of regional political representation (Madleňák 2017; 2019). Three studies (Blažek and Kostelecký 1991; Gyárfášová and Krivý 2012; Madleňák and Balažovič 2018) use cluster analysis, while Netorová-Dická and Molnár (2013) work with factor analysis.

Less often used methods include ecological inference methods (Bahna and Krivý 2016; Bahna et al. 2018; Lysek et al. 2020), spatial econometrics (Plešivčák 2014b), component analysis (Kerekeš 2020), and regional typization (Plešivčák 2013b). Plešivčák (2014a) conducted a study review dealing with elections in urban and rural regions. The only study out of 99 that was not quantitatively focused, using qualitative data analysis instead, is the study by Mikešová (2019). Mikešová (2019) analyzed nine focus group discussions and 44 in-depth interviews across 10 Czech localities.

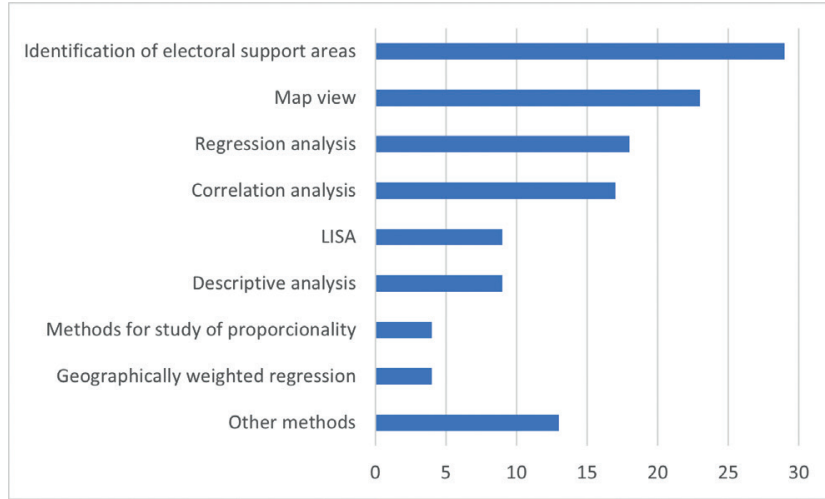

Fig. 3 Division of studies by methods (\%).

\subsection{Geographical scale of study}

Both Czechia and Slovakia use a three-tier territorial-administrative system: regions, districts, and municipalities. Most often, analyses were performed at the district level (51 studies). The second most frequent territorial unit studied are municipalities, with which 39 studies work. Two studies work with regions (Mikuš and Gurňák 2012; Charvát 2016).

Studies examining election results in specific cities used data at the borough level (Plešivčák 2013a; Kerekeš 2018) or the level of electoral districts (Bahna and Majo 2012; Bahna et al. 2018; Kerekeš 2020). The study by Fňukal (2008) also works with electoral district territorial units.

Eight studies work with a territorial unit of functional urban regions (Plešivčák 2011a; 2011b; 2012a; 2012b; 2012c; 2013b; 2014b). Some studies analyze the election results from 1918 to 1938 using historical juridical districts as a territorial unit (Daněk 1993; Kostelecký et al. 2014; Král 2016). Jehlička and Sýkora (1991) and Šimon (2015) also work with juridical districts.

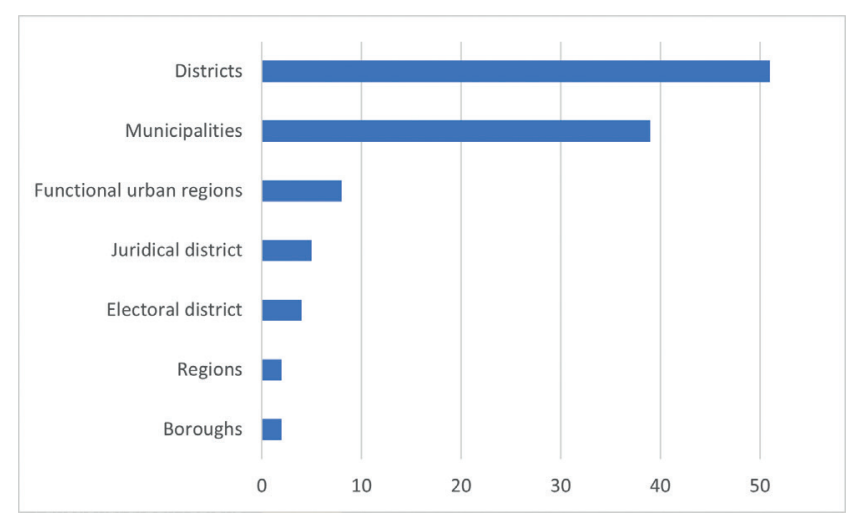

Fig. 4 Division of studies by geographical scale (\%).

\section{Discussion and conclusion}

This systematic review of literature on electoral geography in Czechia and Slovakia has shown several significant trends. Most studies focus on identifying factors that influence election results. The second most common topic is the study of specific elections. This theme was dominate among geographers in the 1990s but, later, appears mainly within chapters of books analyzing not only the geographical aspects of elections but also the political, sociological, economic, or psychological. Other more frequent topics are the analysis of the urban and rural environment influences on voting behavior or studies showing the longterm stability of electoral support for political parties. Given the democratic history of interwar Czechoslovakia and the availability of data, studies also analyze the historical results of the elections. Several studies deal with the electoral support of political parties and political families. However, established political parties are analyzed in most cases, and authors have only begun to address new political families, such as the populist radical right, in recent years. Little attention is paid to the topics of turnout and geographical representation.

Many studies are not based on any theoretical basis, the most used of which was cleavage theory. From the point of view of methods, quantitative methods dominate. The identification of electoral support areas is used to display election results on a map. In the last decade, some authors have also used LISA analysis to show the distribution of results. Regression and correlation analysis are used to determine the factors influencing election results. Analysis based on districts and municipalities as spatial units of analysis was most often used, but some studies also used historical territorial units or functional urban regions.

In comparison to global trends, a positive feature in the state of electoral geography study within Czechia and Slovakia is that the number of studies have increased and they are increasingly being published in journals with impact factor and Scopus indexed 
journals, whereas the number of electoral geography studies have been decreasing globally in recent years (Leib and Quinton 2011). The systematic review showed that all three of Reynolds's (1990) issues are represented. Most studies belong to the geography of voting. Geographical influences on voting and the geography of representation are less represented in Czech and Slovak studies but the number has been rising in recent years. Czech and Slovak electoral geography has also considered some global research trends, which were identified by Madleňák (2010). No study reflected the spatial context of election campaigns or the spatial organization of elections. According to Leib and Quinton's (2011) classification, all the analyzed studies belong among "vote studies" and are situated within the spatial-analytic tradition. Studies about the (re)districting process and electoral system research studies are missing in both countries. Czech and Slovak electoral geography should develop studies from post-structuralist viewpoints to be published.

This systematic review contributes to a deeper understanding of electoral geography in Czechia and Slovakia. The findings may help researchers identify less used themes, theories, and methods of electoral geography. The study also presents an approach to operationalize, analyze, and synthesize literature which may analogously be applied elsewhere.

\section{References}

Baboš, P., Malová, D. (2015): Ekologická analýza výsledkov parlamentných volieb v roku 2012 a prezidentských volieb v roku 2014: možnosti a limity štrukturálnych vysvetlení. Sociológia - Slovak Sociological Review 47(4), 340-364.

Bahna, M., Kerekeš, D., Majo, J. (2018): Vol'by 2016 v Bratislave a Košiciach: ako volia vel'ké slovenské mestá? In: V. Krivý, (ed.), Slovenské vol'by 2016 retrospektívne analýzy, 141-171, Bratislava: Sociologický ústav SAV.

Bahna, M., Krivý, V. (2016): Ako volili národnosti a konfesie v parlamentných vol’bách roku 1929 na Slovensku. Možnosti nových metód ekologickej inferencie. Historický časopis 64(1), 57-86.

Bahna, M., Majo, J. (2012): Bratislava zblízka. Vol’by '12 a '10. In: V. Krivý, (ed.), Slovenské vol'by '12: čo im predchádzalo, postoje a výsledky, 203-235, Bratislava: Sociologický ústav SAV.

Bahna, M., Zagrapan, J. (2017): Volia voliči v obciach s rómskou populáciou L'SNS častejšie? Analýza individuálnych a kontextuálnych faktorov volebných rozhodnutí v parlamentných vol’bách 2016. Bratislava: Sociologický ústav SAV.

Balík, S. (2006): Kontinuita či diskontinuita voličských vzorců? Volební podpora KSČ a KSČM v prostoru dnešního Olomouckého kraje v období 1929-1935 a 1996-2002. Evropská volební studia 1(1), 38-60.

Baráth, J., Szöllös, J., Černák, P. (1995): Analýza stability územia volebnej podpory vybraných politických strán (na základe výsledkov volieb 1990, 1992 a 1994). Geografický časopis 47(4), 247-259.
Bernard, J., Kostelecký, T., Šimon, M. (2014): Existují prostorové kontextové vlivy na volební chování i v relativně nacionalizovaném stranickém systému? Př́klad Česka. Geografie 119(3), 240-258, https://doi .org/10.37040/geografie2014119030240.

Blažek, J., Kostelecký, T. (1991): Geografická analýza výsledků parlamentních voleb v roce 1990. Geografie 96(1), 1-14, https://doi.org/10.37040 /geografie1991096010001.

Brunn, S. D., Vlčková, V. (1994): Parties, candidates and competetive regions in the 1992 Slovak National Council elections. Geografický časopis 46(3), 231-240.

Clem, R. S. (2006): Russia's Electoral Geography: A Review. Eurasian Geography and Economics 47(4), 381-406, https://doi.org/10.2747/1538-7216.47.4.381.

Cook, D. J., Sackett D. L., Spitzer, W. O. (1995): Methodologic guidelines for systematic reviews of randomized control trials in health care from the Potsdam Consultation on Meta-Analysis. Journal of Clinical Epidemiology 48(1), 167-171, https://doi .org/10.1016/0895-4356(94)00172-m.

Daněk, P. (1993): Communist landscapes of Moravia and Silesia (1925-1992). Scripta Facultatis Scientarum Naturalium Universitatis Masarykianae Brunensis Geography 23, 9-24.

Daněk, P. (2000): Existuje politická kultura českého pohraničí? Geografie 105(1), 50-68, https://doi .org/10.37040/geografie2000105010050.

Fňukal, M. (2008): The first general elections on the territory of the present-day Czech Republic: Gerrymandering or malapportionment? Geographia. Studia et Dissertationes 30, 69-83.

Gurňák, D., Mikuš, R. (2012): Odraz rómskej otázky vo volebnom správaní Slovenska - politicko-geografická analýza. Geographia Cassioviensis 6(2), 18-27.

Gyárfášová, O., Krivý, V. (2013): Vzorce voličského správania. In: V. Krivý (ed.), Ako sa mení slovenská spoločnost', 257-342, Bratislava: Sociologický ústav SAV.

Charvát, J. (2016): Národní nebo bratislavská rada? Celostátní volební obvod, proporcionalita a teritoriální zastoupení ve slovenských parlamentních volbách. Sociológia - Slovak Sociological Review 48(5), 431-453.

Jehlička, P., Sýkora, L. (1991): Stabilita regionální podpory tradičních politických stran v českých zemích (19201990). Geografie 96(2), 81-95, https://doi .org/10.37040/geografie1991096020081.

Jehlička, P., Kostelecký, T., Sýkora, L. (1993): Czechoslovak parliamentary elections 1990: old patterns, new trends and lots of suprises. In: J. O'Loughlin, H. van der Wusten (eds.), The new political geography of Eastern Europe, 235-254, London and New York: Belhaven Press.

Johnston, R. (2005): Anglo-American electoral geography: Same root and same goals, but different means and ends? The Professional Geographer 57(4), 580-587, https://doi.org/10.1111/j.1467-9272.2005.00500.x.

Jokić, M., Mervar, A., Mateljan, S. (2019): The development of political science in Central and Eastern Europe: bibliometric perspective, 1996-2013. European Political Science 18(3), 491-509, https://doi.org/10.1057 /s41304-018-0191-6.

Kerekeš, D. (2018): Vol'by 2016 v Košiciach: priestorová analýza. Sociológia - Slovak Sociological Review 52(3), 245-272, https://doi.org/10.31577/sociologia .2020.52.3.11. 
Kerekeš, D. (2020): The City as an Onion? Case Studies of Electoral Geography in Prague and Warsaw. Sociológia Slovak Sociological Review 50(1), 31-56, https://doi .org/10.31577/sociologia.2020.52.3.11.

Kevický, D. (2020a): Priestorové rozloženie volebnej účastni v parlamentných vol'bách v slovenských okresoch v rokoch 1990 až 2016. Geographia Cassioviensis 14(1), 64-76, https://doi.org/10.33542/GC2020-1-04.

Kevický, D. (2020b): Volebná účast' na Slovensku v roku 2020 z pohladu geografie - zmena alebo stabilita? Acta Geographica Universitatis Comenianae 65(2), 161-178.

Kevický, D., Daněk, P. (2020): Kde sa chodí volit’? Faktory ovplyvňujúce geografické rozloženie volebnej účasti v slovenských parlamentných vol'bách. Geografický časopis 72(1), 5-25, https://doi.org/10.31577 /geogrcas.2020.72.1.01.

Kostelecký, T. (1994): Economic, social and historical determinants of voting patterns - In the 1990 and 1992 Parliamentary elections in the Czech Republic. Czech Sociological Review 2(2), 209-228, https://doi.org /10.13060/00380288.1994.30.12.14.

Kostelecký, T. (2001): Vzestup nebo pád politického regionalizmu? Změny na politické mapě v letech 1992 až 1998 - srovnání České a Slovenské republiky. Praha: Sociologický ústav AV ČR.

Kostelecký, T. (2005): Political behavior in metropolitan areas in the Czech Republic between 1990 and 2002 Patterns, trends and the relation to suburbanization and its socio-spatial patterns. Praha: Sociologický ústav AV ČR.

Kostelecký, T. (2009): Regionální rozdíly ve volebních výsledcích v České republice - parlamentní volby 1996-2006. Evropská volební studia 4(2), 124-134.

Kostelecký, T., Krivý, V. (2015): Urbánno-rurálne rozdiely voličského správania v Česku a na Slovensku. Sociológia - Slovak Sociological Review 47(4), 390-413.

Kostelecký, T., Mikešová, R., Poláková, M., Čermák, D., Bernard, J., Šimon, M. (2014): Koho volí Vaši sousedé: prostorové vzorce volebního chování na území Česka od roku 1920 do roku 2006, jejich změny a možné prŕíčiny. Praha: Sociologický ústav AV ČR.

Kostelecký, T., Mikešová, R., Poláková, M., Čermák, D., Bernard, J., Šimon, M. (2015): Geografie výsledků parlamentních voleb: vzorce volebního chování v Česku 1992-2013. Praha: Sociologický ústav AV ČR.

Kouba, K. (2007): Prostorová analýza českého stranického systému. Institucionalizace a prostorové režimy. Czech Sociological Review 43(5), 1017-1037, https://doi.org /10.13060/00380288.2007.43.5.08.

Král, O. (2016): National and class aspects of electoral support for the Communist Party of Czechoslovakia. Acta Universitatis Palackianae Olomucensis - Geographica 47(2), 37-58.

Krivý, V. (1999): Územné celky a skupiny obcí v parlamentných vol'bách 1998' Sociológia - Slovak Sociological Review 31(1), 51-77.

Krivý, V. (2003): Volebné výsledky a trendy. In: G. Mesežnikov, O. Gyárfášová, M. Kollár (eds.), Slovenské vol'by 02' - výsledky, dôsledky, súvislosti, 61-106, Bratislava: Inštitút pre verejné otázky.

Krivý, V. (2006): Parlamentné vol'by 2006: staré a nové vzorce rozdelení voličských hlasov. In G. Mesežnikov, O. Gyárfášová, M. Kollár (eds.), Slovenské vol'by 06' výsledky, príčiny, súvislosti, 143-205, Bratislava: Inštitút pre verejné otázky.
Krivý, V. (2011): Voliči v parlamentných vol'bách 2010 analýza volebných výsledkov. In: Z. Bútorová, 0 . Gyárfášová, G. Mesežnikov, M. Kollár (eds.), Slovenské vol'by 10' - šanca na zmenu, 97-142, Bratislava: Inštitút pre verejné otázky.

Krivý, V. (2012): Výsledky volieb '12: čo sa zmenilo, čo zostáva. In: V. Krivý (ed.), Slovenské vol'by '12: čo im predchádzalo, postoje a výsledky, 47-136, Bratislava: Sociologický ústav SAV.

Krivý, V., Feglová, V., Balko, D. (1996): Slovensko a jeho regióny - sociokultúrne súvislosti volebného správania. Bratislava: Nadácia Médiá.

Krivý, V., Majo, J. (2018): Parlamentné vol'by 2016 v retrospektíve: komu boli naklonené relevantné prostredia? In: V. Krivý (ed.), Slovenské vol'by 2016 retrospektívne analýzy, 55-140, Bratislava: Sociologický ústav SAV.

Kyloušek, J, Pink, M. (2007): Electoral support for the Communist Party of Bohemia and Moravia in parliamentary elections in the Czech Republic after 1990. Evropská volební studia 2(2), 149-163.

Kyloušek, J., Pink, M. (2009): Voličská základna sociálnedemokratických stran v bývalém Československu a její prostorové proměny. Evropská volební studia 4(1), $1-21$.

Leib, J., Quinton, N. (2011): On the Shores of the "Moribund Backwater"?: Trends in Electoral Geography Research Since 1990. In: B. Warf, J. Leib (eds.), Revitalizing Electoral Geography, 9-27, Farnham: Ashgate.

Lösel, F., King, S., Bender, D., Jugl, I. (2018): Protective factors against extremism and violent radicalization: A systematic review of research. International Journal of Developmental Science 12, 89-102, https://doi .org/10.3233/DEV-170241.

Lysek, J., Zvada, L., Škop, M. (2020): Mapping the 2020 Slovak Parliamentary Election. Analysis of Spatial Support and Voter Transition. Politologický časopis - Czech Journal of Political Science 27(3), 278-302, https://doi.org/10.5817/PC2020-3-278.

Madleňák, T. (2006): Politicko-geografická analýza volebných preferencií obyvatelov regiónu Oravy. Geografická revue 2(2), 630-649.

Madleňák, T. (2010): Hlavné trendy výskumu v súčasnej volebnej geografii. Geografický časopis 62(2), 127-145.

Madleňák, T. (2012) Regionálna diferenciácia volebného správania na Slovensku (1998- 2010). Bratislava: Veda.

Madleňák, T. (2017): Potenciálna a reálna politická reprezentácia regiónov Slovenska. Geographia Cassioviensis 11(2), 153-166.

Madleňák, T. (2019): Geografická reprezentativita poslancov NR SR zvolených v podmienkach jedného volebného obvodu. Sociológia - Slovak Sociological Review 51(5), 48--501, https://doi.org/10.31577 /sociologia.2019.51.5.22.

Madleňák, T., Balažovič, L'. (2018): Politické preferencie miest na Slovensku v parlamentných vol'bách 1929. Geografie 123(1), 107-140, https://doi.org/10.37040 /geografie2018123010107.

Manning N., Edwards K. (2014): Does civic education for young people increase political participation? A systematic review. Educational Review 66(1), 22-45, https://doi.org/10.1080/00131911.2013.763767.

Mariot, P. (1991): Priestorové hodnotenie výsledkov volieb do Slovenskej národnej rady (jún 1990). Geografický časopis 43(3), 231-249. 
Mariot, P. (1994): Vol'by do SNR v roku 1992 a ich porovnanie s vol'bami v roku 1990. Geographica Slovaca 7, 103-110.

Mariot, P. (1996): Spatial aspects of the 1994 elections for the National Council of the Slovak Republic. Moravian Geographical Reports 4(1), 52-60.

Mariot, P. (1999): Štruktúra volebných preferencií obyvatel'ov najväčších miest Slovenska. Geografický časopis 51(2), 153-174.

Mariot, P. (2003a): Electoral behaviour of the Hungarians living on the territory of the Slovak Republic. Földrajzi Értesítõ 52(1-2), 63-74.

Mariot, P. (2003b): Teritoriálne aspekty volebnej podpory HZDS. Geografický časopis 55(1), 3-19.

Mariot, P. (2004): Regionálne aspekty akceptovania nových subjektov na slovenskej politickej scéne. Geografie 109(1), 1-14, https://doi.org/10.37040/geografie2004 109010001.

Maškarinec, P. (2011): Volební podpora ČS(D)SD, (KDU)ČSL, KSČ(M) a ODS v prostoru dnešního Libereckého kraje v letech 1920-1935 a 1996-2010: Kontinuita či diskontinuita voličských vzorců? Evropská volební studia 6(1), 22-43.

Maškarinec, P. (2014) Volební geografie Libereckého kraje 1992-2010. Voličské chování z pohledu explorační prostorové analýzy dat (ESDA). Brno: Centrum pro studium demokracie a kultury.

Maškarinec, P. (2015): Nekonečný příběh. Pokračující stabilita voličské podpory Komunistické strany Čech a Moravy v parlamentních volbách 2006-2013. Politické vedy 18(3), 135-160.

Maškarinec, P. (2017a): A Spatial Analysis of Czech Parliamentary Elections, 2006-2013. Europe-Asia Studies 69(3), 426-457, https://doi.org/10.1080 /09668136.2017.1313962.

Maškarinec, P. (2017b): The Czech pirate party in the 2010 and 2013 Parliamentary elections and the 2014 European parliament elections: Spatial analysis of voter support. Slovak Journal of Political Science 17(1), 5-33, https://doi.org/10.1515/sjps-2017-0001.

Maškarinec, P. (2019): The rise of new populist political parties in Czech parliamentary elections between 2010 and 2017: the geography of party replacement. Eurasian Geography and Economics 60(5), 511-547, https://doi .org/10.1080/15387216.2019.1691928.

Maškarinec, P. (2020a): Analýza prostorové podpory a stranického nahrazení na příkladu hnutí Starostové a nezávislí (STAN): Vstup nového subjektu do stranického systému České republiky. Politické vedy 23(1), 8-31, https://doi.org/10.24040

/politickevedy.2020.23.1.8-31.

Maškarinec, P. (2020b): Crossing the left-right party divide? Understanding the electoral success of the Czech Pirate Party in the 2017 parliamentary elections. Politics 40(4), 510-526, https://doi.org/10.1177/0263395720920768.

Maškarinec, P., Bláha, P. (2014): For whom the Bell Tolls: Grievance Theory and the Rise of New Political Parties in the 2010 and 2013 Czech Parliamentary Elections. Sociológia - Slovak Sociological Review 46(6), 706-731.

Mikešová, R. (2019): Vliv lokálního prostředí na volební chování v Česku. Geografie 124(4), 411-432, https://doi .org/10.37040/geografie2019124040411.

Mikešová, R., Kostelecký, T. (2016): Geografická reprezentativita poslanců zvolených do Poslanecké sněmovny českého parlamentu za první republiky (1918-1938) a po roce 1989. Středoevropské politické studie 18(4), 354-380, https://doi.org/10.5817 /CEPSR.2016.4.354.

Mikuš, R. (2014): Politická diferenciácia územia Slovenska z pohladu volebných preferencií. In: V. Lauko (ed.), Regionálne dimenzie Slovenska, 67-125, Bratislava: Univerzita Komenského.

Mikuš, R., Gurňák, D. (2012): Vývoj pozícií politického extrémizmu, radikalizmu a nacionalizmu v rôznych úrovniach volieb na Slovensku. Geografické informácie 16(2), 38-49, https://doi.org/10.17846 /GI.2012.16.2.38-49.

Mikuš, R., Gurňák, D. (2014): Špecifiká volebnej účasti v obciach Košického kraja vo vol'bách na rôznych úrovniach v rokoch 1999-2014. Geographia Cassioviensis 8(2), 150-161.

Mikuš, R., Gurňák, D. (2016): Rómska otázka ako jeden z mobilizačných faktorov volebnej podpory krajnej pravice na Slovensku a v Mad’arsku. Geographia Cassioviensis 10(1), 29-46.

Mikuš, R., Gurňák, D. (2019): Demokraticky k autokracii? Analýza volebnej podpory krajnej pravice na Slovensku, v Mad’arsku a Rumunsku. Bratislava: Univerzita Komenského.

Mikuš, R., Máliková, L. (2015): Patterns of electoral behavior in marginal rural communes: case study from eastern Slovakia. Human Geographies - Journal of Studies and Research in Human Geography 9(1), 57-78, https://doi.org/10.5719/hgeo.2015.91.5.

Navrátil, V. (2010): Volební geografie a parlamentní volby v České republice 2010. Evropská volební studia 5(2), 183-205.

Nestorová-Dická, J., Molnár, P. (2013): Geografické aspekty volebnej podpory politických strán na Slovensku v parlamentných vol'bách 2012. Geographia Cassioviensis 7(2), 50-62.

Nielsen, S. W. (2017): On political brands: A systematic review of the literature. Journal of Political Marketing 16, 118146, https://doi.org/10.1080/15377857.2014.959694.

Novotný, J., Hasman, J., Lepič, M. (2018): Contextual factors and motivations affecting rural community sanitation in low- and middle-income countries: A systematic review. International Journal of Hygiene and Environmental Health 221, 121-133, https://doi.org/10.1016 /j.ijheh.2017.10.018.

Nový, M. (2014): Volební účast v předčasných volbách. In V. Havlík, O. Eibl, M. Gregor, K. Gregor, L. Hrbková, R. Chytilek, E. Kneblová, T. Maceček, A. Macková, M. Nový, M. Pink, P. Spáč, J. Šedo, P. Voda (eds.), Volby do Poslanecké sněmovny 2013, 161-187, Brno: Masarykova univerzita.

Pink, M. (2011): The 2010 Slovak Elections in the Light of Previous Results. Evropská volební studia 6(1), 3-21.

Pink, M., Eibl, O., Havlík, V., Madleňák, T., Spáč, P., Voda, P. (2012): Volební mapy České a Slovenské republiky po roce 1993: vzorce, trendy, proměny. Brno: Centrum pro studium demokracie a kultury.

Pink, M., Voda, P. (2014): Volby do Poslanecké sněmovny 2013 a volební geografie. In: V. Havlík, O. Eibl, M. Gregor, K. Gregor, L. Hrbková, R. Chytilek, E. Kneblová, T. Maceček, A. Macková, M. Nový, M. Pink, P. Spáč, J. Šedo, P. Voda (eds.), Volby do Poslanecké sněmovny 2013, 215-237, Brno: Masarykova univerzita. 
Plešivčák, M. (2011a): Postavenie regiónov Slovenska z hladiska územnej volebnej podpory politických strán v parlamentných vol'bách v rokoch 2002-2010. Geografický časopis 63(3), 227-251.

Plešivčák, M. (2011b): Regionálny obraz korelačnej závislosti medzi volebnými preferenciami a vybranými sociálnymi charakteristikami populácie Slovenska. Regionální studia 5(1), 2-16.

Plešivčák, M. (2012a): Charakteristika regiónov východného Slovenska z hladiska socio-politického konfliktu medzi mestským a vidieckym priestorom. Geographia Cassoviensis 6(1), 37-47.

Plešivčák, M. (2012b): Politicko-preferenčné štiepenie spoločnosti vo funkčných mestských regiónoch stredného Slovenska na báze urbánno-rurálne dichotómie priestoru v období rokov 1998-2010. Acta Geographica Universitatis Comenianae 56(1), 99-122.

Plešivčák, M. (2012c): State of Urban-Rural Cleavage in Electoral Preferences Caused by Socio-Political Situation in Functional Urban Regions of Western Slovakia. Acta Universitatis Palackianae Olomucensis - Geographica 43(2), 83-99.

Plešivčák, M. (2013a): Politický život Bratislavy z perspektívy jej volebného správania. In: J. Buček, P. Korec (eds.), Moderná humánna geografia mesta Bratislava: priestorové štruktúry, siete a procesy, 257-312, Bratislava: Univerzita Komenského.

Plešivčák, M. (2013b): The Regional Dimension of the Socio-Political Urban-Rural Conflict in Slovakia. Acta Universitatis Carolinae Geographica 48(1), 47-58, https://doi.org/10.14712/23361980.2015.10.

Plešivčák, M. (2014a): Otázka politického správania obyvatel’ov vidieka a mesta v krajinách bývalého východného bloku so špeciálnym akcentom situácie na Slovensku. Acta Geographica Universitatis Comenianae 58(2), 229-242.

Plešivčák, M. (2014b): Socio-ekonomická kompozícia spoločnosti a jej vplyv na teritoriálne vzorce volebného správania - prípadová štúdia regiónov západného Slovenska. Sociológia - Slovak Sociological Review 46(1), 25-59.

Plešivčák, M., Buček, J., Bačík, V., Kusendová, D. (2016): Theoretical and methodological notes on current options related to examination of voting behaviour - The geographical approach. Acta Geographica Universitatis Comenianae 60(2), 151-170.

Przybyla, V. (2019): Vliv vybraných demografických charakteristik na volební chování na Slovensku v meziválečném období. Geografický časopis 71 (2), 181199, https://doi.org/10.31577/geogrcas.2019.71.2.10.

Reynolds, D. R. (1990): Whither electoral geography? A critique. In: R. Johnston, F. M. Shelley, P. J. Taylor (eds.), Developments in Electoral Geography, 22-35, London: Routledge, https://doi.org/10.4324/9781315749747.

Rybář, M., Spáč, P., Voda, P., Nemčok, M. (2017) Po stopách politického zemětřesení: parlamentní volby na Slovensku v roce 2016. Brno: Centrum pro studium demokracie a kultury.

Spurná, P. (2008): Geograficky vážená regrese: metoda analýzy prostorové nestacionarity geografických jevů. Geografie 113(2), 125-139, https://doi.org/10.37040 /geografie2008113020125.
Szabó, B., Tátrai, P. (2016): Regional and social cleavages in the Slovak elections after the change of the regime. Geografický časopis 68(3), 195-212.

Szöllös, J. (2000): Stabilita území volebnej podpory vybraných politických strán a ich zoskupení na Slovensku v rokoch 1990-1998. Geografický časopis 52(3), 243-267.

Szöllös, J. (2006): Regióny volebnej podpory vybraných politických strán v parlamentných vol’bách 1998, 2002 a 2006. Geografická revue 2(2), 650-669.

Šerý, M., Urbančíkova, N. (2011): Elections to the Chamber of Deputies of the National Assembly in the Hlučín region in 1929. Acta Universitatis Palackianae Olomucensis Geographica 42(2), 91-106.

Šimon, M. (2015): Measuring phantom borders: the case of Czech/Czechoslovakian electoral geography. Erdkunde 69(2), 139-150, http://dx.doi.org/10.3112/erdkunde .2015 .02 .04 .

Šuška, P., Šveda, M., Krivý, V. (2018): Hodnotová zmena v zázemí Bratislavy ako dôsledok sub-urbánneho rozvoja: analýza volebného správania. Sociológia Slovak Sociological Review 50(5), 609-631, https://doi .org/10.31577/sociologia.2018.50.5.23.

Van Hamme, G., Vandermotten, C., Lockhart, P. M. (2018): The electoral geography of the left in western Europe since 1945: Permanencies and changes. Tijdschrift voor economische en sociale geografie 109(2), 274-294, https://doi.org/10.1111/tesg.12280.

Virendrakumar, B., Jolley, E., Badu, E., Schmidt E. (2018): Disability inclusive elections in Africa: a systematic review of published and unpublished literature. Disability \& Society 33(4), 509-538, https://doi.org /10.1080/09687599.2018.1431108.

Voda, P. (2011): Geografie volební podpory KDU-ČSL 1920 až 2010. Evropská volební studia 6(2), 104-127.

Voda, P. (2015): Jaká je role postkomunismu? Volební geografie České a Rakouské republiky v letech 1990-2013. Brno: Centrum pro studium demokracie a kultury.

Voda, P. (2019): Volby do Poslanecké sněmovny 2017 a volební geografie. In: O. Eibl, M. Gregor, P. Dvořák, V. Dostálová, P. Spáč, P. Voda, J. Šedo, V. Havlík (eds.), Volby do Poslanecké sněmovny v roce 2017, 189-212, Brno: Centrum pro studium demokracie a kultury.

Voda, P., Pink, M. (2015): Explanation of spatial differentiation of electoral results in the Czech Republic and Slovak Republic. Communist and Post-Communist Studies 48(4), 301-316, https://doi.org/10.1016 /j.postcomstud.2015.09.002.

Weaver, R. (2014): Contextual influences on political behavior in cities: Toward urban electoral geography. Geography Compass 8(12), 874-891, https://doi .org/10.1111/gec3.12186.

Wright, R. W., Brand, R. A., Dunn, W., Spindler, K. P. (2007): How to write a systematic review. Clinical orthopaedics and related research 455, 23-29, http://dx.doi.org /10.1097/BL0.0b013e31802c9098.

Zarycki, T. (2015): The electoral geography of Poland: Between stable spatial structures and their changing interpretations. Erdkunde 69(2), 107-124, http://dx.doi .org/10.3112/erdkunde.2015.02.02. 


\section{Appendix 1}

List of analyzed studies detailing topic, theoretical frame, method, and geographical scale.

\begin{tabular}{|c|c|c|c|c|}
\hline References & Study theme & Theoretical background & Methods & Scale of study \\
\hline Baboš and Malová (2015) & $\begin{array}{l}\text { factors influencing geographic } \\
\text { differences in electoral results }\end{array}$ & cleavage theory & regression analysis & districts \\
\hline Bahna et al. (2018) & urban/rural aspects of elections & without theory & $\begin{array}{l}\text { identification of electoral } \\
\text { support areas, ecological } \\
\text { inference }\end{array}$ & $\begin{array}{l}\text { electoral } \\
\text { districts }\end{array}$ \\
\hline Bahna and Krivý (2016) & historical-geographic analysis & without theory & ecological inference & districts \\
\hline Bahna and Majo (2012) & urban/rural aspects of elections & without theory & map view & $\begin{array}{l}\text { electoral } \\
\text { districts }\end{array}$ \\
\hline Bahna and Zagrapan (2017) & $\begin{array}{l}\text { factors influencing geographic } \\
\text { differences in electoral results }\end{array}$ & without theory & regression analysis & municipalities \\
\hline Balík (2006) & historical-geographic analysis & without theory & $\begin{array}{l}\text { identification of electoral } \\
\text { support areas }\end{array}$ & municipalities \\
\hline Baráth et al. (1995) & area of electoral support & without theory & $\begin{array}{l}\text { identification of electoral } \\
\text { support areas }\end{array}$ & districts \\
\hline Bernard et al. (2014) & $\begin{array}{l}\text { factors influencing geographic } \\
\text { differences in electoral results }\end{array}$ & contextual effect & ecological regression & municipalities \\
\hline Blažek and Kostelecký (1991) & study of one election & without theory & $\begin{array}{l}\text { cluster analysis, regression } \\
\text { analysis }\end{array}$ & districts \\
\hline Brunn and Vlčková (1994) & territorial representation & without theory & descriptive analysis & districts \\
\hline Daněk (1993) & historical-geographic analysis & without theory & regression analysis & juridical districts \\
\hline Daněk (2000) & urban/rural aspects of elections & without theory & map view, descriptive analysis & districts \\
\hline Fňukal (2008) & historical-geographic analysis & without theory & $\begin{array}{l}\text { methods for study of } \\
\text { proportionality }\end{array}$ & $\begin{array}{l}\text { electoral } \\
\text { districts }\end{array}$ \\
\hline Gurňák and Mikuš (2012) & $\begin{array}{l}\text { factors influencing geographic } \\
\text { differences in electoral results }\end{array}$ & without theory & correlation analysis & municipalities \\
\hline Gyárfášová and Krivý (2012) & $\begin{array}{l}\text { study analyzing multiple } \\
\text { elections }\end{array}$ & without theory & $\begin{array}{l}\text { cluster analysis, identification of } \\
\text { electoral support areas }\end{array}$ & $\begin{array}{l}\text { districts, } \\
\text { municipalities }\end{array}$ \\
\hline Charvát (2016) & territorial representation & without theory & $\begin{array}{l}\text { methods for study of } \\
\text { proportionality }\end{array}$ & regions \\
\hline Jehlička and Sýkora (1991) & area of electoral support & without theory & $\begin{array}{l}\text { identification of electoral } \\
\text { support areas }\end{array}$ & juridical districts \\
\hline Jehlička et al. (1993) & $\begin{array}{l}\text { study analyzing multiple } \\
\text { elections }\end{array}$ & without theory & $\begin{array}{l}\text { identification of electoral } \\
\text { support areas }\end{array}$ & districts \\
\hline Kerekeš (2018) & urban/rural aspects of elections & cleavage theory & $\begin{array}{l}\text { regression analysis, } \\
\text { identification of electoral } \\
\text { support areas }\end{array}$ & boroughs \\
\hline Kerekeš (2020) & urban/rural aspects of elections & $\begin{array}{l}\text { conceptual sociological } \\
\text { structure of city }\end{array}$ & component analysis & $\begin{array}{l}\text { electoral } \\
\text { districts }\end{array}$ \\
\hline Kevický (2020a) & voter turnout & voter turnout theories & $\begin{array}{l}\text { identification of electoral } \\
\text { support areas }\end{array}$ & districts \\
\hline Kevický (2020b) & voter turnout & voter turnout theories & LISA, regression analysis & municipalities \\
\hline Kevický and Daněk (2020) & voter turnout & voter turnout theories & regression analysis & municipalities \\
\hline Kostelecký (1994) & $\begin{array}{l}\text { factors influencing geographic } \\
\text { differences in electoral results }\end{array}$ & cleavage theory & regression analysis & districts \\
\hline Kostelecký (2001) & $\begin{array}{l}\text { factors influencing geographic } \\
\text { differences in electoral results }\end{array}$ & without theory & regression analysis & districts \\
\hline Kostelecký (2005) & urban/rural aspects of elections & without theory & $\begin{array}{l}\text { regression analysis, correlation } \\
\text { analysis }\end{array}$ & municipalities \\
\hline Kostelecký (2009) & $\begin{array}{l}\text { factors influencing geographic } \\
\text { differences in electoral results }\end{array}$ & without theory & regression analysis & districts \\
\hline Kostelecký and Krivý (2015) & urban/rural aspects of elections & without theory & descriptive analysis & municipalities \\
\hline
\end{tabular}




\begin{tabular}{|c|c|c|c|c|}
\hline References & Study theme & Theoretical background & Methods & Scale of study \\
\hline Kostelecký et al. (2014) & historical-geographic analysis & without theory & $\begin{array}{l}\text { identification of electoral } \\
\text { support areas }\end{array}$ & juridical districts \\
\hline Kostelecký et al. (2015) & area of electoral support & without theory & $\begin{array}{l}\text { identification of electoral } \\
\text { support areas }\end{array}$ & districts \\
\hline Kouba (2007) & $\begin{array}{l}\text { factors influencing geographic } \\
\text { differences in electoral results }\end{array}$ & contextual effect & LISA, regression analysis & districts \\
\hline Král (2016) & historical-geographic analysis & without theory & $\begin{array}{l}\text { correlation analysis, } \\
\text { identification of electoral } \\
\text { support areas }\end{array}$ & juridical districts \\
\hline Krivý (1999) & study of one election & without theory & map view, descriptive analysis & $\begin{array}{l}\text { districts, } \\
\text { municipalities }\end{array}$ \\
\hline Krivý (2003) & study of one election & without theory & $\begin{array}{l}\text { descriptive analysis, } \\
\text { identification of electoral } \\
\text { support areas }\end{array}$ & districts \\
\hline Krivý (2006) & study of one election & without theory & $\begin{array}{l}\text { descriptive analysis, } \\
\text { identification of electoral } \\
\text { support areas }\end{array}$ & districts \\
\hline Krivý (2011) & study of one election & without theory & $\begin{array}{l}\text { descriptive analysis, } \\
\text { identification of electoral } \\
\text { support areas }\end{array}$ & $\begin{array}{l}\text { districts, } \\
\text { municipalities }\end{array}$ \\
\hline Krivý (2012) & study of one election & without theory & $\begin{array}{l}\text { descriptive analysis, } \\
\text { identification of electoral } \\
\text { support areas }\end{array}$ & $\begin{array}{l}\text { districts, } \\
\text { municipalities }\end{array}$ \\
\hline Krivý et al (1996) & $\begin{array}{l}\text { factors influencing geographic } \\
\text { differences in electoral results }\end{array}$ & without theory & $\begin{array}{l}\text { correlation analysis, } \\
\text { identification of electoral } \\
\text { support areas }\end{array}$ & districts \\
\hline Krivý and Majo (2018) & study of one election & without theory & $\begin{array}{l}\text { descriptive analysis, } \\
\text { identification of electoral } \\
\text { support areas }\end{array}$ & $\begin{array}{l}\text { districts, } \\
\text { municipalities }\end{array}$ \\
\hline Kyloušek and Pink (2007) & political parties/families & without theory & $\begin{array}{l}\text { correlation analysis, } \\
\text { identification of electoral } \\
\text { support areas }\end{array}$ & districts \\
\hline Kyloušek and Pink (2009) & political parties/families & without theory & $\begin{array}{l}\text { correlation analysis, } \\
\text { identification of electoral } \\
\text { support areas }\end{array}$ & districts \\
\hline Lysek et al. (2020) & $\begin{array}{l}\text { factors influencing geographic } \\
\text { differences in electoral results }\end{array}$ & cleavage theory & $\begin{array}{l}\text { regression analysis, } \\
\text { geographically weighted } \\
\text { regression, ecological inference }\end{array}$ & municipalities \\
\hline Madleňák (2006) & $\begin{array}{l}\text { study analyzing multiple } \\
\text { elections }\end{array}$ & without theory & map view & municipalities \\
\hline Madleňák (2012) & $\begin{array}{l}\text { study analyzing multiple } \\
\text { elections }\end{array}$ & cleavage theory & $\begin{array}{l}\text { correlation analysis, } \\
\text { identification of electoral } \\
\text { support areas }\end{array}$ & districts \\
\hline Madleňák (2017) & territorial representation & without theory & $\begin{array}{l}\text { methods for study of } \\
\text { proportionality }\end{array}$ & districts \\
\hline Madleňák (2019) & territorial representation & without theory & $\begin{array}{l}\text { methods for study of } \\
\text { proportionality }\end{array}$ & districts \\
\hline Madleňák and Balažovič (2018) & historical-geographic analysis & cleavage theory & cluster analysis & municipalities \\
\hline Mariot (1991) & study of one election & without theory & map view & municipalities \\
\hline Mariot (1994) & study of one election & without theory & descriptive analysis & districts \\
\hline Mariot (1996) & study of one election & without theory & map view & districts \\
\hline Mariot (1999) & urban/rural aspects of elections & without theory & map view, descriptive analysis & municipalities \\
\hline Mariot (2003a) & political parties/families & without theory & correlation analysis & $\begin{array}{l}\text { districts, } \\
\text { municipalities }\end{array}$ \\
\hline Mariot (2003b) & political parties/families & without theory & map view & municipalities \\
\hline Mariot (2004) & political parties/families & without theory & map view, descriptive analysis & municipalities \\
\hline Maškarinec (2011) & historical-geographic analysis & without theory & $\begin{array}{l}\text { identification of electoral } \\
\text { support areas }\end{array}$ & municipalities \\
\hline
\end{tabular}




\begin{tabular}{|c|c|c|c|c|}
\hline References & Study theme & Theoretical background & Methods & Scale of study \\
\hline Maškarinec (2014) & $\begin{array}{l}\text { factors influencing geographic } \\
\text { differences in electoral results }\end{array}$ & contextual effect & $\begin{array}{l}\text { LISA, geographically weighted } \\
\text { regression }\end{array}$ & municipalities \\
\hline Maškarinec (2015) & area of electoral support & contextual effect & LISA & districts \\
\hline Maškarinec (2017a) & area of electoral support & contextual effect & LISA & districts \\
\hline Maškarinec (2017b) & area of electoral support & contextual effect & LISA & districts \\
\hline Maškarinec (2019) & area of electoral support & contextual effect & LISA & districts \\
\hline Maškarinec (2020a) & area of electoral support & contextual effect & LISA & municipalities \\
\hline Maškarinec (2020b) & political parties/families & contextual effect & $\begin{array}{l}\text { LISA, geographically weighted } \\
\text { regression }\end{array}$ & municipalities \\
\hline Maškarinec and Bláha (2014) & $\begin{array}{l}\text { factors influencing geographic } \\
\text { differences in electoral results }\end{array}$ & grievance theory & regression analysis & districts \\
\hline Mikešová (2019) & $\begin{array}{l}\text { factors influencing geographic } \\
\text { differences in electoral results }\end{array}$ & contextual effect & qualitative data analysis & municipalities \\
\hline Mikešová and Kostelecký (2016) & territorial representation & without theory & $\begin{array}{l}\text { map view, methods for study of } \\
\text { proportionality }\end{array}$ & districts \\
\hline Mikuš (2014) & $\begin{array}{l}\text { study analyzing multiple } \\
\text { elections }\end{array}$ & without theory & map view, correlation analysis & $\begin{array}{l}\text { districts, } \\
\text { municipalities }\end{array}$ \\
\hline Mikuš and Gurňák (2012) & political parties/families & without theory & descriptive analysis & $\begin{array}{l}\text { regions, } \\
\text { municipalities }\end{array}$ \\
\hline Mikuš and Gurňák (2014) & voter turnout & without theory & map view & municipalities \\
\hline Mikuš and Gurňák (2016) & political parties/families & without theory & map view, correlation analysis & districts \\
\hline Mikuš and Gurňák (2019) & political parties/families & cleavage theory & regression analysis & $\begin{array}{l}\text { districts, } \\
\text { municipalities }\end{array}$ \\
\hline Mikuš and Máliková (2015) & urban/rural aspects of elections & without theory & map view, descriptive analysis & municipalities \\
\hline Navrátil (2010) & study of one election & without theory & $\begin{array}{l}\text { correlation analysis, } \\
\text { identification of electoral } \\
\text { support areas }\end{array}$ & districts \\
\hline $\begin{array}{l}\text { Nestorová-Dická and Molnár } \\
\text { (2013) }\end{array}$ & $\begin{array}{l}\text { factors influencing geographic } \\
\text { differences in electoral results }\end{array}$ & without theory & factor analysis & districts \\
\hline Nový (2014) & voter turnout & without theory & map view, correlation analysis & $\begin{array}{l}\text { districts, } \\
\text { municipalities }\end{array}$ \\
\hline Pink (2011) & study of one election & without theory & $\begin{array}{l}\text { identification of electoral } \\
\text { support areas }\end{array}$ & districts \\
\hline Pink et al. (2012) & $\begin{array}{l}\text { study analyzing multiple } \\
\text { elections }\end{array}$ & cleavage theory & $\begin{array}{l}\text { regression analysis, } \\
\text { identification of electoral } \\
\text { support areas }\end{array}$ & districts \\
\hline Pink and Voda (2014) & study of one election & without theory & $\begin{array}{l}\text { identification of electoral } \\
\text { support areas }\end{array}$ & districts \\
\hline Plešivčák (2011a) & area of electoral support & without theory & map view & $\begin{array}{l}\text { functional urban } \\
\text { regions }\end{array}$ \\
\hline Plešivčák (2011b) & $\begin{array}{l}\text { factors influencing geographic } \\
\text { differences in electoral results }\end{array}$ & without theory & correlation analysis & $\begin{array}{l}\text { functional urban } \\
\text { regions }\end{array}$ \\
\hline Plešivčák (2012a) & urban/rural aspects of elections & without theory & map view, descriptive analysis & $\begin{array}{l}\text { functional urban } \\
\text { regions }\end{array}$ \\
\hline Plešivčák (2012b) & urban/rural aspects of elections & without theory & map view, descriptive analysis & $\begin{array}{l}\text { functional urban } \\
\text { regions }\end{array}$ \\
\hline Plešivčák (2012c) & urban/rural aspects of elections & without theory & map view, descriptive analysis & $\begin{array}{l}\text { functional urban } \\
\text { regions }\end{array}$ \\
\hline Plešivčák (2013a) & urban/rural aspects of elections & cleavage theory & map view, descriptive analysis & boroughs \\
\hline Plešivčák (2013b) & urban/rural aspects of elections & without theory & regional typization & $\begin{array}{l}\text { functional urban } \\
\text { regions }\end{array}$ \\
\hline Plešivčák (2014a) & urban/rural aspects of elections & cleavage theory & review & municipalities \\
\hline Plešivčák (2014b) & $\begin{array}{l}\text { factors influencing geographic } \\
\text { differences in electoral results }\end{array}$ & cleavage theory & spatial econometrics & $\begin{array}{l}\text { functional urban } \\
\text { regions }\end{array}$ \\
\hline Przybyla (2019) & historical-geographic analysis & without theory & correlation analysis & districts \\
\hline Rybář et al. (2017) & study of one election & without theory & correlation analysis & districts \\
\hline
\end{tabular}




\begin{tabular}{|c|c|c|c|c|}
\hline References & Study theme & Theoretical background & Methods & Scale of study \\
\hline Spurná (2008) & $\begin{array}{l}\text { factors influencing geographic } \\
\text { differences in electoral results }\end{array}$ & without theory & $\begin{array}{l}\text { geographically weighted } \\
\text { regression }\end{array}$ & municipalities \\
\hline Szabó and Tátrai (2016) & political parties/families & cleavage theory & map view & municipalities \\
\hline Szöllös (2000) & area of electoral support & without theory & $\begin{array}{l}\text { identification of electoral } \\
\text { support areas }\end{array}$ & districts \\
\hline Szöllös (2006) & area of electoral support & without theory & $\begin{array}{l}\text { identification of electoral } \\
\text { support areas }\end{array}$ & districts \\
\hline Šerý and Urbančíková (2011) & historical-geographic analysis & without theory & $\begin{array}{l}\text { correlation analysis, } \\
\text { identification of electoral } \\
\text { support areas }\end{array}$ & municipalities \\
\hline Šimon (2015) & $\begin{array}{l}\text { factors influencing geographic } \\
\text { differences in electoral results }\end{array}$ & $\begin{array}{l}\text { theory of phantom } \\
\text { borders }\end{array}$ & map view & juridical districts \\
\hline Šuška et al. (2018) & urban/rural aspects of elections & without theory & map view & municipalities \\
\hline Voda (2011) & historical-geographic analysis & without theory & $\begin{array}{l}\text { identification of electoral } \\
\text { support areas }\end{array}$ & districts \\
\hline Voda (2015) & $\begin{array}{l}\text { factors influencing geographic } \\
\text { differences in electoral results }\end{array}$ & cleavage theory & regression analysis & $\begin{array}{l}\text { districts, } \\
\text { municipalities }\end{array}$ \\
\hline Voda (2019) & study of one election & without theory & correlation analysis & districts \\
\hline Voda and Pink (2015) & $\begin{array}{l}\text { factors influencing geographic } \\
\text { differences in electoral results }\end{array}$ & cleavage theory & regression analysis & municipalities \\
\hline
\end{tabular}

